\title{
Use of Immunoglobulins in Prevention and Treatment of Infection in Critically Ill Patients: Review and Critique
}

\author{
Giorgio Zanetti, Michel P. Glauser, \\ and Jean-Daniel Baumgartner
}

From the Division of Infectious Diseases, Centre Hospitalier Universitaire Vaudois, Lausanne, Switzerland

\begin{abstract}
The study of the use of standard intravenous immunoglobulin (IVIG) preparations as adjunctive therapy for seriously ill patients is motivated by the need to restore immunoglobulin $\mathbf{G}$ depleted because of trauma or surgery and/or by the need to provide patients with specific antibodies to various microorganisms. Whereas no clinical studies have shown that standard IVIG has therapeutic efficacy, some data suggest that its prophylactic use is beneficial. Antisera or IVIG prepared from individuals who are hyperimmunized with the biologically active, highly conserved core portion of the endotoxin of gram-negative bacteria confer variable degrees of protection in animal models and clinical trials. Two clinical trials with use of monoclonal antibodies to core lipopolysaccharide have been completed. Only subsets of patients with gram-negative sepsis were protected by the monoclonal antibodies, but the results of the studies were discrepant in regard to the specific characteristics of patients who benefited from the administration of these antibodies. Further studies will be necessary to establish whether this therapy can be recommended for critically ill patients.
\end{abstract}

Critically ill patients are at high risk for infection as a result of several immunologic dysfunctions. Decreased levels of IgG have been reported in such patients, especially after trauma and surgery [1]. Moreover, the efficacy of their neutrophils undergoes a decline with respect to exhibition of chemotaxis, opsonic activity, and ability to kill bacteria. In addition, such patients are exposed to a wide variety of organisms in the hospital environment, a circumstance which further increases the probability of infection. The administration of intravenous immunoglobulin (IVIG) to critically ill patients might enhance host defense by restoring IgG and/or by providing patients with specific antibodies to various microorganisms or constituents of microorganisms. IVIG might also attenuate the inflammatory process engendered by the host response to bacterial products such as endotoxin. Two approaches have been used in the administration of IVIG for treatment of critically ill patients: (1) administration of standard IVIG (nonspecific use) and (2) administration of whole plasma, immunoglobulin preparations, or monoclonal antibodies (MoAbs) directed against the endotoxin constituent of gram-negative bacteria (specific use).

This article is part of a series of papers in the present issue of Reviews on the evolving use of biologicals in the treatment and prevention of infectious diseases. The papers were presented at a symposium held during the Interscience Conference on Antimicrobial Agents and Chemotherapy in October 1990 in Atlanta. The symposium was súpported by an educational grant from Amgen Inc., Thousand Oaks, California.

Reprints and correspondence: Prof. Michel P. Glauser, Division of Infectious Diseases, Department of Internal Medicine, Centre Hospitalier Universitaire Vaudois, 1011 Lausanne, Switzerland.

Reviews of Infectious Diseases 1991;13:985-92

(C) 1991 by The University of Chicago. All rights reserved. $0162-0886 / 91 / 1305-0048 \$ 02.00$

\section{Nonspecific Use of IVIG}

Treatment of infections. IVIG can be administered to patients therapeutically for infections. In an unblinded, randomized, controlled clinical trial with 104 surgical intensive care patients, Just and colleagues [2] administered four 100$\mathrm{mL}$ doses of IVIG (Pentaglobin; Biotest Pharma, Frankfurt, Germany) over 2 days in conjunction with antibiotics to 50 patients at the first sign of infection. Fifty-four control patients received antibiotics alone. The mortality attributed to infections and the overall mortality of the IVIG and control groups did not differ. The IVIG reportedly was effective for patients preoperatively classified as "high risk," but since this result was obtained in only one of several subgroups, the data should be interpreted cautiously. In a multicenter, unblinded, randomized, controlled clinical trial among 288 patients with fibrinopurulent peritonitis, Jesdinsky and co-workers [3] administered $10 \mathrm{~g}$ of an IVIG preparation (immunoglobulin $7 \mathrm{~S}$ human iv; Armour Pharmaceuticals, Eschwege, Germany) to 145 patients; a control group that consisted of 143 patients was not treated. The study failed to demonstrate the efficacy of IVIG therapy, however. One possible explanation for such a result is that the amount of specific antibodies might have been insufficient to confer protection against the large number of pathogenic bacteria.

Prophylactic use of IVIG. IVIG can also be administered prophylactically. Two reports of studies using this approach have been published. Duswald and colleagues [4] administered $2.5 \mathrm{~g}$ of IVIG (Intraglobulin; Biotest Pharma) to 150 critically ill patients, but the investigators observed no protective effects with respect to wound infection, urinary tract infection, or pneumonia. Glinz and associates [5] administered $36 \mathrm{~g}$ ( $12 \mathrm{~g}$ on days 0,5 , and 12 after admission to the inten- 
sive care unit) of IVIG (Sandoglobulin; Sandoz, Basel, Switzerland) to 150 patients and observed a decrease in the incidence of pneumonia. This benefit was not unequivocally proven, however, since pneumonia was mainly defined radiologically and microbiologic documentation was questionable.

Recently, Cometta and co-workers [6] completed a blinded, placebo-controlled clinical trial with two IVIG preparations. A $400 \mathrm{mg} / \mathrm{kg}$ dose of standard preparation (Gammagard; Hyland Therapeutics Division, Glendale, CA) was administered to 109 patients when they were admitted to the surgical intensive care unit and once a week thereafter. A second preparation of IVIG, which was enriched with antibodies to the core lipopolysaccharide (LPS) of Salmonella minnesota R595 (Re LPS) (see next section), was administered to 108 patients. The titer of the antibodies to core LPS in this preparation was eightfold higher than that in the standard IVIG. A control arm of 112 patients received albumin. The standard IVIG preparation accounted for a reduction in the number of patients who developed infections during the course of the study (36\%, versus $53 \%$ in the control group; $P<.05$ ). The reduction was caused by a significant decline in the number of cases of pneumonia $(P<.05)$.

Therefore, it appears that standard IVIG can have a protective effect when administered to high-risk surgical patients as a prophylactic measure. Indeed, detailed analysis of the results showed that both the stay in the intensive care unit and the entire duration of hospitalization were shorter for those patients who received standard IVIG than for those who received albumin. It is surprising that the IVIG enriched with antibodies to the endotoxin core failed to protect the patients from infection. The preparation conferred no protection against gram-negative sepsis, septic shock, or focal infections; the reason for this is unclear.

\section{Antibodies to Gram-Negative Bacteria}

It is well known that the toxicity of gram-negative bacteria is caused by the toxic LPS, called endotoxin, that constitutes the outer bacterial membrane. The endotoxin molecules consist of the toxic moiety, a lipoidal acylated glucosamine disaccharide (lipid A), which is linked to a polysaccharide side chain (called $\mathrm{O}$ antigen) through an intermediate oligosaccharide region, the core. Antibodies to the intact LPS are produced mainly in opposition to the side chains, which are highly antigenic. Because side chains vary widely between strains, these antibodies have a very narrow specificity. By contrast, the core is highly conserved and is very similar in different strains.

In the 1970s, Braude et al. [7], Ziegler et al. [8], and McCabe [9] all hypothesized that by stimulating production of antibodies to the highly conserved core moiety of LPS, one could obtain cross-reacting antibodies that would protect against a wide variety of gram-negative bacteria. This was ultimately accomplished by using the Escherichia coli mu- tant $\mathrm{J5}$, a rough mutant of $E$. coli 0111:B4 that lacks the enzyme uridine 5'-diphosphonate-galactose 4-epimerase; this defect prevents attachment of the side chains to the core. Therefore, in the J5 strain, the polysaccharide side chains of the endotoxin are missing and the core is exposed. In animals, immunization with LPS from $E$. coli $\mathrm{J} 5$ or with whole $E$. coli J5 bacterial cells results in high titers of antibody to epitopes of the LPS core [10]. Another rough mutant that has been studied for its ability to stimulate production of antibodies to the core region is an $\operatorname{Re}$ mutant of $S$. minnesota.

Researchers have postulated that antibodies elicited by these two rough mutants should afford protection against a wide range of gram-negative bacteria by a mechanism requiring two steps: (1) these antibodies recognize epitopes of the core region shared by the LPS of pathogenic gram-negative bacteria, and (2) the postulated binding neutralizes the endotoxic properties of LPS, i.e., leads to a suppression or attenuation of the release of mediators such as cytokines. However, neither of these two hypothetical steps has been unequivocally demonstrated. The following sections review what has been learned from studies in which the $\mathrm{J} 5$ mutant and other rough mutants were used.

Studies with animals. Ziegler and colleagues have shown that granulocytopenic rabbits challenged in the conjunctival sac with Pseudomonas aeruginosa develop a massive, lethal pseudomonal infection [11] and that these rabbits could be protected with $E$. coli $\mathbf{J} 5$ antiserum. Some of their results with use of purified immunoglobulins from human volunteers immunized with $E$. coli $\mathrm{J} 5$ are reproduced in table 1 [12]. Braude et al. [7], McCabe [9], and other researchers [8, 13-18] have also found that animals were protected when they were actively or passively immunized with the rough mutant J5 of $E$. coli or with an Re rough mutant of $S$. minnesota.

Some investigators, however, were unable to obtain similar results [19-28]. For instance, Greisman and Johnston [27] found that mice inoculated with LPS from $S$. minnesota, Salmonella typhimurium, E. coli 0127 , or $E$. coli 0111 were not protected by either of the two antisera to the J5 and Re mutants; the mortality among these mice was even greater than the mortality for mice that received only saline. The study revealed that only antibody to the strain-specific LPS was protective (table 2).

Thus, the results of animal studies described in this section

Table 1. Level of protection of neutropenic rabbits from lethal pseudomonal bacteremia after intravenous administration of immunoglobulin from humans immunized with $E$. coli $\mathrm{J} 5$.

\begin{tabular}{lc} 
Source of immunoglobulin & $\begin{array}{l}\text { No. of deaths/no. of } \\
\text { rabbits treated }(\%)^{*}\end{array}$ \\
\hline $\begin{array}{l}\text { Nonimmunized human } \\
\text { Immunized human }\end{array}$ & $\begin{array}{r}12 / 14(86) \\
3 / 14(21)\end{array}$ \\
\hline NOTE. Reprinted with permission from [12]. & \\
$* P=.001\left(\chi^{2}\right.$ test).
\end{tabular}


Table 2. Level of protection (in terms of mortality) noted in mice after pretreatment with various preparations* and inoculation with $230 \mu \mathrm{g}$ of LPS from $S$. typhimurium.

\begin{tabular}{lc} 
Pretreatment preparation $(0.5 \mathrm{~mL})$ & $\begin{array}{c}\text { Percentage of deaths/ } \\
\text { no. of mice inoculated }\end{array}$ \\
\hline Saline & $52 / 25$ \\
Antiserum to $E$. coli $\mathrm{J} 5 \dagger$ & $75 / 12$ \\
Preimmune serum & $64 / 11$ \\
Antiserum to $E$. coli $\mathrm{J} 5 \ddagger$ & $83 / 12$ \\
Preimmune serum & $83 / 12$ \\
Antiserum to $S$. typhimurium & $0 / 25 \S$ \\
\hline NOTE. Adapted with permission from $[27]$. & \\
$*$ The $E$. coli J5 antisera were prepared by using the method of Braude et al. [7]. \\
$\ddagger$ Serum from rabbit 25. \\
$\$$ Serum from rabbit 26. \\
$\$ P<.0005$, compared with the other trials.
\end{tabular}

show that only some researchers have been successful in demonstrating that antibodies to core glycolipids can be protective. There is no simple explanation for the discrepant results of studies with various preparations of antibodies to core LPS. The precise specificities as well as the mode of action of the antibodies tested have not been clarified. Moreover, the animal models studied, the mode of challenge, and the nature of LPS or of bacteria used for challenge are parameters that all could have an impact on the protective efficacy of these preparations [29].

However, these considerations cannot explain all the discrepancies in data; varying results were sometimes obtained despite the use of similar antibodies, similar animal models, and similar bacterial or LPS challenges $[8,9,26,27,30]$. Therefore, it can be postulated that additional, unknown negative or positive factors sometimes operate. For instance, an artifact (now well recognized) can result when the antibody preparation to be tested is contaminated by LPS. Minute amounts of LPS administered prophylactically induce a state of tolerance to LPS and protect animals against subsequent bacterial or LPS challenges [31, 32]. Since antibodies tested in studies of protection almost uniformly are administered before bacterial or LPS challenge, the occurrence of such an artifact in many earlier-reported experiments cannot be ruled out. Moreover, the interpretation of data from experimental studies of protection with use of rabbit antisera may depend on whether preimmune and immune sera came from the same rabbit or from different rabbits [27]; it has been shown that sera from nonimmunized rabbits, unlike other sera, may have a natural protective power against challenge with gramnegative bacteria or LPS.

Similarly, in studies of protection with use of MoAbs, the degree of purification is critical to the results. Indeed, ascitic and hybridomal fluids can contain various proteins and peptides, such as cytokines, some of which might be able to bind to LPS or to induce some tolerance to LPS in experimental animals. Most experimental studies of protection that have been reported, including those by Teng et al. [30] and Young
Table 3. Mortality among patients with gram-negative bacteremia after administration of control serum from nonimmunized donors or antiserum from donors immunized with $E$. coli J5.

\begin{tabular}{|c|c|c|c|}
\hline \multirow[b]{2}{*}{ Patient group } & \multicolumn{2}{|c|}{$\begin{array}{l}\text { No. of deaths/no. of patients } \\
\text { treated }(\%) \text { in group } \\
\text { receiving indicated } \\
\text { therapeutic serum }\end{array}$} & \multirow[b]{2}{*}{$P$ value } \\
\hline & $\begin{array}{l}\text { Control serum } \\
\text { (mean titer, } \\
1: 6 \text { ) }\end{array}$ & $\begin{array}{c}\text { Antiserum } \\
\text { (mean titer, } \\
1: 32 \text { ) }\end{array}$ & \\
\hline All patients & $38 / 100(38)$ & $22 / 91(24)$ & .04 \\
\hline Patients in profound shock & $26 / 34(76)$ & $17 / 37(46)$ & .009 \\
\hline
\end{tabular}

et al. [33], have involved ascitic or hybridomal fluids. Experimental variability might account for important differences in survival rates noted from one experiment to another, so the reporting of only part of the experiments might introduce some element of bias $[34,35]$. In conclusion, the precise description of the control preparation and of the preparation containing antibody is critical for the interpretation of experimental data from studies with animals.

Clinical studies. As was the case with the animal studies described in the previous section, only some of the data from clinical studies indicated that patients could be successfully treated or protected with administered antibodies.

In 1982 Ziegler and co-workers [36] reported a pioneering randomized, blind, controlled study of patients with gramnegative bacteremia who received either serum from healthy volunteers who had been vaccinated with heat-killed $E$. coli J5 or control serum obtained from the same donors before immunization. There was a fivefold difference in the mean titers of antibody to the LPS of $E$. coli J5 in the control and immune serum. These sera were administered to 304 patients, 191 of whom had gram-negative bacteremia. The results (table 3 ) led to the conclusion that human $E$. coli $\mathrm{J} 5$ antiserum substantially reduces mortality due to gram-negative bacteremia and septic shock. Regarding the mode of protection, Ziegler et al. [36] hypothesized that antibodies to $E$. coli J5, which were present in the serum after immunization, became bound to some part of the endotoxin core of pathogenic gramnegative bacteria and sterically prevented lipid $A$ from reacting with mediators of shock in blood and tissue fluid. This hypothesis could not be convincingly confirmed, however, since the outcome could not be significantly correlated with the level of antibody to $E$. coli $\mathrm{J} 5$ measured in the serum administered to patients.

In a randomized, double-blind, prophylactic trial, Baumgartner and colleagues [37] were able to show that plasma from volunteers immunized with $E$. coli $\mathrm{J} 5$ protected surgical patients who were at high risk for gram-negative infection from shock and death. On admission to the intensive care 
Table 4. Prophylaxis of surgical patients for gram-negative shock with plasma from nonimmunized donors or from donors immunized with $E$. coli $\mathrm{J} 5$.

\begin{tabular}{lccc}
\hline & $\begin{array}{c}\text { No. of patients treated } \\
\text { with plasma from } \\
\text { indicated type of donor }\end{array}$ & \\
\cline { 2 - 3 } Patient group & $\begin{array}{c}\text { Non- } \\
\text { immunized }\end{array}$ & Immunized & $\begin{array}{c}P \\
\text { value }\end{array}$ \\
\hline All patients & 136 & 126 & $\ldots$ \\
with focal GN infections & 55 & 45 & NS \\
who developed GN shock & 15 & 6 & .049 \\
who died of GN shock & 9 & 2 & .033 \\
Patients who underwent & & & \\
abdominal surgery & 83 & 71 & $\ldots$ \\
who developed GN shock & 13 & 2 & .006 \\
who died of GN shock & 9 & 1 & .017 \\
\hline
\end{tabular}

NOTE. GN $=$ gram-negative; NS $=$ not significant. Adapted with permission from [37].

unit, patients received plasma harvested from donors who had been immunized against $E$. coli $\mathrm{J} 5$; the control group received plasma taken from these same donors before immunization. Six of 126 patients $(4.8 \%)$ who received plasma from immunized donors and 15 of 136 patients $(11.0 \%)$ in the control group developed gram-negative shock; the numbers of related deaths in each group were two $(1.6 \%)$ and nine $(6.6 \%)$, respectively $(P<.05$, one-tailed Fisher exact test). The difference between the two groups was observed mainly in patients who underwent abdominal surgery (table 4): Although administration of plasma with antibodies to $E$. coli J5 failed to decrease the incidence of gram-negative infection, it greatly reduced the most serious consequences of such infections. As was noted in the report by Ziegler et al. [36], protection was related to immune plasma, not to specific levels of antibody to core LPS in a given plasma (D. Heumann and J-D Baumgartner, unpublished data).

Two other studies, however, have failed to demonstrate that any beneficial effect results from the administration of $E$. coli J5 antiserum. McCutchan and colleagues [38] studied neutropenic patients as well as patients receiving bone marrow transplants. These patients were given $E$. coli $\mathrm{J} 5$ antiserum as a prophylactic measure. The results did not suggest that the antiserum prevented gram-negative bacteremia or the occurrence of fever that, for at least some of these patients, was considered to be caused by release of endotoxin from the gut. One possible explanation for this failure to demonstrate such a beneficial effect could be the low power of the study, since the number of infections due to gram-negative bacteria was small. Recently, we conducted a blind study in which 73 children with purpura fulminans received either control plasma (33 patients) or plasma with antibodies to the core LPS of E. coli J5 (40 patients) (E. Girardin and J-D Baumgartner, submitted for publication). There was no difference in mor- tality between the two groups, a fact suggesting that the plasma from donors immunized with $E$. coli $\mathrm{J} 5$ was not effective in the treatment of meningococcal septicemia.

As already noted, in both successful clinical studies with $E$. coli $\mathrm{J} 5$ antiserum $[36,37]$, the protection remained of unclear origin because outcome could not be convincingly correlated with the level of antibodies to the core LPS of $E$. coli J5 ([36] and D. Heumann and J-D Baumgartner, unpublished data). In addition, it was found that in 70 volunteers who donated their plasma for one of these studies [37], immunization with $E$. coli $\mathrm{J} 5$ vaccine (provided by $\mathrm{E}$. J. Ziegler) induced a modest threefold increase in antibodies to the LPS of $E$. coli $\mathrm{J} 5$ but no increase in antibodies to Re LPS or to lipid A [39]. Thus, the protection afforded by $E$. coli J5 antiserum could not be attributable to antibodies to the LPS of $E$. coli J5, to Re LPS, or to lipid A.

IVIG enriched with antibodies to the LPS core has been purified from serum of immunized volunteers or from serum of donors with naturally acquired high levels of antibodies to LPS. Calandra and colleagues [40], in a randomized, double-blind trial, compared the efficacy of IVIG collected from volunteers who were immunized with $E$. coli J5 with that of standard IVIG (Sandoglobulin) in the treatment of 71 patients with gram-negative septic shock. There was a 2.2fold increase in titer of antibody to the LPS of $E$. coli J5 in the preparation from the hyperimmunized donors compared with that in the standard IVIG. No difference between the two groups in terms of mortality was reported.

As previously noted, Cometta and co-workers [6] compared IVIG that contained antibodies to core LPS, which was collected from blood donors with naturally high levels of Re antibodies, with standard IVIG or placebo in a prophylactic double-blind study. In contrast to the efficacy of standard IVIG, no protection was afforded by the IVIG with core LPS antibodies. One hypothetical explanation for the ineffectiveness of IVIG with antibodies to core LPS is that IgM antibodies, which were absent from IVIG preparations, might be necessary for protection [15]. However, since the precise specificity and the mode of action of antibodies to core LPS are unknown, there is no strong basis for such a claim. Although some experimental data suggested that IgM-enriched serum fractions were more effective than IgG-enriched fractions [15], other studies had found that IgG antibodies were as effective or even more effective than IgM $[17,41]$.

This review of the clinical trials performed with antisera or polyclonal immunoglobulin reveals that, among six studies, four were unsuccessful in demonstrating the efficacy of the administered preparations. The data emphasize the need for an understanding of which factors were responsible for the protective effects noted in the successful studies with serum or plasma and, in addition, which of these factors were absent from the unsuccessful studies with plasma or immunoglobulin preparations. 


\section{Studies With Monoclonal Antibodies}

In recent years, several MoAbs have been developed that recognize various epitopes of the core region of endotoxin $[30,33,42-52]$. Two of these MoAbs, both of the IgM class, have been tested for treatment of patients with gram-negative infections.

First, Young and associates [33] made murine MoAbs to the endotoxin core of the J5 mutant of $E$. coli and of the Re mutant of $S$. minnesota. They immunized BALB/c mice against these bacterial strains and could produce IgM MoAbs to Re LPS or lipid A. The ability of these MoAbs to prevent or treat infection was then tested in female mice. The authors found that these antibodies were not protective when administered alone [33], but one of them, an IgM MoAb to lipid A called E5, appeared to be synergistic with antibiotics in experimental studies of prophylactic or therapeutic methods.

For instance, mice were injected with a dose of live serumresistant bacteria (three challenge organisms were used) that would be expected to kill $80 \%-100 \%$ of the animals. Two hours after onset of infection, a mixture of antibiotics was injected intramuscularly; control mice received saline. After an additional 2 hours, the MoAb E5 was injected intravenously.

There were four treatment groups, with 14 mice per group and per challenge organism. Group A received antibiotics alone; $45 \%$ survived (results of challenges with the three organisms were pooled). Group $B$ received antibiotics and MoAbs; $64 \%$ survived $(P<0.05$, one-tailed, in comparison with group $A$ when the results of the three bacterial challenges were combined). For group $\mathrm{C}$ (which received MoAbs and saline) $29 \%$ survival was noted, and for group D (which received saline alone) $24 \%$ survival was noted.

In another experiment, the MoAb E5 was used for the treatment of infections due to two strains of $P$. aeruginos $a$ in mice. Again, E5 alone had no protective effect, but when the results for the two strains were combined, treatment with E5 and antibiotics was significantly more effective than treatment with antibiotics alone. These studies suggested, therefore, that E5 might have a protective effect in some experimental conditions. However, definitive conclusions are difficult to draw because ascitic fluid, not purified antibody, was used and because individual experiments had to be pooled to obtain statistically significant differences.

In a clinical study of the MoAb E5 [53], patients with a suspected gram-negative septic syndrome were randomly assigned to receive intravenously either the antibody $(2 \mathrm{mg} / \mathrm{kg}$ daily for 2 consecutive days) or an identical volume of saline. Of the 468 evaluable patients, 316 had a documented gramnegative infection. No decrease in mortality was observed in this group of patients. However, when the results in subgroups were analyzed, there was a statistically significant decrease in mortality among the 137 patients who were not in shock when enrolled in the study $(P=.03)$, whereas the $179 \mathrm{pa}$ - tients who were in shock were not protected. Shock was defined as refractory hypotension; patients with organ failure or disseminated intravascular coagulation were not considered to be in shock if they had a systolic pressure $>90 \mathrm{~mm}$ $\mathrm{Hg}$. Among patients who were not in shock, a comparable reduction in mortality occurred in the bacteremic group as well as the nonbacteremic group. Administration of E5 was safe in that $<2 \%$ of patients developed allergic adverse effects. Because the results of this study suggested that E5 was effective only in a subgroup of patients who were not in shock (an unanticipated finding), a confirmatory multicenter study has been initiated.

The second MoAb, subsequently designated as HA-1A, was produced by Teng and co-workers [30] from a hybridoma obtained by fusing $B$ lymphocytes from human spleen with heteromyeloma cells. The researchers used splenocytes taken from one patient with Hodgkin's disease who was undergoing splenectomy and who had previously been vaccinated with the J5 mutant of $E$. coli. They reported that the MoAb reacted in vitro with many unrelated species of gram-negative bacteria. Moreover, the MoAb in hybridomal fluid was shown to be protective against endotoxin in the dermal Shwartzmann reaction in rabbits and against gram-negative bacteremia in mice. Protection appeared to be specific for gram-negative bacteria because the MoAb to $E$. coli J5 failed to protect against the pneumococcus, a gram-positive organism that lacks endotoxin. The results of ELISAs and binding inhibition experiments led to the conclusion that the MoAb specifically recognized lipid A [54].

These experimental observations could not be reproduced, however. Indeed, using purified MoAb instead of crude hybridomal fluid, we could not demonstrate that HA-1A could be protective [26] in models very similar to those used by Teng et al. [30]. In addition, in contrast to type-specific LPS antibodies, HA-1A did not suppress LPS-induced secretion of tumor necrosis factor in mice, a circumstance suggesting that HA-1A was not able to prevent LPS from reaching its target on macrophages [26].

Moreover, it was found that purified HA-1A bound moderately to lipid A and Re LPS but poorly to LPS from pathogenic, smooth, gram-negative bacteria. It bound to a large range of gram-negative bacteria and also to gram-positive bacteria, fungi, and lipids unrelated to lipid $\mathrm{A}$, including cardiolipin and lipoproteins (use of such controls has not been previously reported [30,54]). This broad binding pattern suggested nonspecific interactions with hydrophobic constituents and may bring into question the specificity of HA-1A for lipid A (D. Heumann and J-D Baumgartner, unpublished data).

Ziegler and colleagues [54] administered HA-1A (or albumin as a control preparation) to patients with a presumptive diagnosis of gram-negative sepsis. The patients were randomized to receive a single dose of HA-1A (100 mg intravenously) or a similar volume of human albumin. Of the 543 
patients, 317 had microbiologically documented gramnegative infections; for 200 of the 317 patients, blood cultures were positive at the time of randomization. HA-1A did not reduce the mortality in the overall study population or among the 117 patients with nonbacteremic gram-negative infections. However, there was a significant decrease in mortality among the subgroup of patients with gram-negative bacteremia $(P=.014)$; the decrease in mortality was most obvious among the 101 patients who were in shock when enrolled in the study.

Detailed analysis of these data indicated that, by chance, differences in risk factors between placebo and HA-1A recipients might have been present in the subgroup of 200 patients with gram-negative bacteremia at the time of randomization. Indeed, a total of 101 serious complications (e.g., disseminated intravascular coagulation, adult respiratory distress syndrome, acute hepatic failure, and acute renal failure) [54] were noted at entry in the 95 placebo recipients (mean, 1.06 per patient); 85 such complications were noted in the 105 HA-1A recipients (mean, 0.81 per patient) ( $P=.07$ by comparison of Poisson distributions). The 16 additional serious complications in the placebo group might partially account for the higher mortality (13 more deaths) in this group.

Definitive conclusions for the use of MoAbs to endotoxin core are difficult to draw at present. Indeed, when the HA-1A MoAb was tested experimentally by two independent groups, it showed divergent efficacy that was possibly related to its degree of purification $[26,30]$. The other antibody, the E5 $\mathrm{MoAb}$, only once has been reported to be moderately efficacious in animals when tested as ascitic fluid. Moreover, the clinical results of the studies have been somewhat conflicting. For instance, in one study, the MoAbs protected predominantly patients in shock; in another study, only those patients who were not in shock were protected. In one study, only patients for whom blood cultures were positive were protected by the treatment, while in another study the protection occurred independently of the blood culture status. Thus, further studies are needed to define prospectively and specifically the types of patients who might benefit most from this therapeutic approach.

\section{Conclusions}

According to available study reports, the use of standard IVIG for the treatment of infection in critically ill patients seems ineffective. In contrast, two studies have shown a reduction of infections, mainly pnejumonia, when standard IVIG preparations were administered prophylactically to chosen groups of postsurgical or trauma patients. However, no impact on mortality was demonstrated. Cost-effectiveness studies are therefore warranted.

At present, the treatment of the gram-negative septic syndrome with antibodies to lipid A or other epitopes of the core LPS should still be considered investigational. None of the preparations used in clinical studies has yet emerged as an established therapeutic modality that can be administered routinely to patients with septic shock. In the two studies investigating MoAbs, only subsets of patients with the gramnegative sepsis syndrome were protected, but both studies gave discrepant results concerning the specific characteristics of patients who were reported to benefit from the administration of these antibodies. In addition, the epitope specificity and the mode of action of the MoAbs investigated so far are still unknown. These concerns are not trivial. The indiscriminate use of such treatment might have considerable financial impact: the potential market for such antibodies has been estimated to be worth several billion dollars per year in the western countries.

\section{References}

1. Grob P, Holch M, Fierz W, Glinz W, Geroulanos S. Immunodeficiency after major trauma and selective surgery. Pediatr Infect Dis J 1988; 7(Suppl 5):\$37-42

2. Just HM, Vogel W, Metzger M, Pelka RD, Daschner FD. Treatment of intensive care unit patients with severe nosocomial infections. Intensive Care Med 1986:345-52

3. Jesdinsky HJ, Tenpel G, Castrup HJ, Seifert J. Cooperative group of additional immunoglobulin therapy in severe bacterial infections: results of a multicenter randomized controlled trial in cases of diffuse fibrinopurulent peritonitis. Klin Wochenschr 1987;65:1132-8

4. Duswald KH, Müller K, Seifert J, Rinz J. Wirksamkeit von i.v. Gammaglobulin gegen bakterielle Infektionen chirurgischer Patienten. Münch Med Wschr 1980;122:832-6

5. Glinz W, Grob PJ, Nydegger UE, Ricklin T, Stamm F, Stoffel D, Lasance A. Polyvalent immunoglobulins for prophylaxis of bacterial infections in patients with multiple trauma. Intensive Care Med 1985; 11:288-94

6. Cometta A, Baumgartner JD, Lee M, Glauser MP, the Anti-Core LPSIVIG Collaborative Study Group. Prophylaxis of infection in high risk surgical patients with standard intravenous immunoglobulin $G$ or with antibody to core glycolipid [abstract no. 476]. In: Program and Abstracts of the 30th Interscience Conference on Antimicrobial Agents and Chemotherapy. Washington, DC: American Society for Microbiology, 1990:165

7. Braude AI, Ziegler EJ, Douglas H, McCutchan JA. Antibody to cell wall glycolipid of gram-negative bacteria: induction of immunity to bacteremia and endotoxemia. J Infect Dis 1977;136(Suppl):S167-73

8. Ziegler EJ, Douglas H, Sherman JE, Davis CE, Braude AI. Treatment of $E$. coli and Klebsiella bacteremia in agranulocytic animals with antiserum to a UDP-Gal epimerase-deficient mutant. J Immunol $1973 ; 111: 433-8$

9. McCabe WR. Immunization with R. mutant of $S$. minnesota. I. Protection against challenge with heterologous gram-negative bacilli. J Immunol 1972;108:601-10

10. Baumgartner J-D, O'Brien TX, Kirkland TN, Glauser MP, Ziegler EJ. Demonstration of cross-reactive antibodies to smooth gram-negative bacteria in antiserum to Escherichia coli J5 antiserum. J Infect Dis 1987;156:136-43

11. Ziegler EJ, McCutchan JA, Douglas H, Braude AI. Prevention of lethal Pseudomonas bacteremia with epimerase deficient $E$. coli antiserum. Trans Assoc Am Physicians 1975;88:101-18

12. Braude AI, Ziegler EJ, Douglas H. Treatment of gram-negative bacteremia, endotoxemia, and shock with antibody to core glycolipid. In: Walker RS, Gruber DF, MacVittie TJ, Conklin JJ, eds. Pathophysiol- 
ogy of combined injury and trauma. Baltimore: University Park Press, 1985:201-8

13. Johns M, Skehill A, McCabe WR. Immunization with rough mutants of Salmonella minnesota. IV. Protection by antisera to O and rough antigens against endotoxin. J Infect Dis 1983;147:57-67

14. Sakulramrung R, Domingue GJ. Cross-reactive immunoprotective antibodies to Escherichia coli O111 rough mutant J5. J Infect Dis 1985;151:995-1004

15. McCabe WR, DeMaria A Jr, Berberich H, Johns MA. Immunization with rough mutants of Salmonella minnesota: protective activity of IgM and IgG antibody to the R595 (Re chemotype) mutant. J Infect Dis 1988;158:291-300

16. Dunn DL, Mach PA, Condie RM, Cerra FB. Anticore endotoxin F(ab)2 equine immunoglobulin fragments protect against lethal effects of gramnegative bacterial sepsis. Surgery 1984;96:440-6

17. Davis CE, Ziegler EJ, Arnold K. Neutralization of meningococcal endotoxin by antibody to core glycolipid. J Exp Med 1978;147:1007-17

18. Marks MI, Ziegler EJ, Douglas H, Corbeil LB, Braude AI. Induction of immunity against lethal Haemophilus influenzae type b infection by Escherichia coli core lipopolysaccharide. J Clin Invest 1982; 69:742-9

19. Hodgin LA, Drews J. Effect of active and passive immunizations with lipid A and Salmonella minnesota Re 595 on gram-negative infections in mice. Infection 1976;4:5-10

20. Morris DD, Cullor JS, Whitlock RH, Wickstrom M, Corbeil LB. Endotoxemia in neonatal calves given antiserum to a mutant Escherichia coli (J-5). Am J Vet Res 1986;47:2554-65

21. Ng AK, Chen CLH, Chang CM, Nowotny A. Relationship of structure to function in bacterial endotoxins: serologically cross-reactive components and their effect on protection of mice against some gramnegative infections. J Gen Microbiol 1976;94:107-16

22. Greisman SE, DuBuy JB, Woodward CL. Experimental gram-negative bacterial sepsis: reevaluation of the ability of rough mutant antisera to protect mice. Proc Soc Exp Biol Med 1978;158:482-90

23. Pennington JE, Menkes E. Type-specific vs. cross-protective vaccination for gram-negative pneumonia. J Infect Dis 1981;144:599-603

24. Peter G, Chernow M, Keating M, Ryff JC, Zinner SH. Limited protective effect of rough mutant antisera in murine Escherichia coli bacteremia. Infection 1982;10:228-32

25. Trautmann M, Hahn H. Antiserum against Escherichia coli J5: a reevaluation of its in vitro and in vivo activity against heterologous gramnegative bacteria. Infection $1985 ; 13: 140-5$

26. Baumgartner JD, Heumann D, Gerain J, Weinbreck P, Grau GE, Glauser MP. Association between protective efficacy of anti-lipopolysaccharide (LPS) antibodies and suppression of LPS-induced tumor necrosis factor $\alpha$ and interleukin 6. Comparison of $O$ side chain-specific antibodies with core LPS antibodies. J Exp Med 1990;171:889-96

27. Greisman SE, Johnston CA. Failure of antisera to J5 and R595 rough mutants to reduce endotoxemic lethality. J Infect Dis 1988;157:54-64

28. Weinbreck P, Baumgartner JD, Cometta A, Heumann D, Glauser MP. Failure of passive immunization with rabbit antiserum to $E$. coli $\mathrm{J} 5$ in bacteremia and endotoxemic lethality in mice [abstract no. 622]. In: Program and Abstracts of the 28th Interscience Conference on Antimicrobial Agents and Chemotherapy. Washington, DC: American Society for Microbiology, 1988:218

29. Ziegler EJ. Protective antibody to endotoxin core: the emperor's new clothes? J Infect Dis"1988;158:286-90

30. Teng NNH, Kaplan HS, Hebert JM, Moore C, Douglas H, Wunderlich A, Braude AI. Protection against gram-negative bacteremia and endotoxemia with human monoclonal IgM antibodies. Proc Natl Acad Sci U S A 1985;82:1790-4

31. Woods JP, Black JR, Barritt DS, Connell TD, Cannon JG. Resistance to meningococcemia apparently conferred by anti- $\mathrm{H} .8$ monoclonal antibody is due to contaminating endotoxin and not to specific immunoprotection. Infect Immun 1987;55:1927-8
32. Chong KT, Huston M. Implications of endotoxin contamination in the evaluation of antibodies to lipopolysaccharides in a murine model of gram-negative sepsis. J Infect Dis 1987;156:713-9

33. Young LS, Gascon R, Alam S, Bermudez LE. Monoclonal antibodies for treatment of gram-negative infections. Rev Infect Dis 1989;11(Suppl 7):S1564-71

34. DeMaria A Jr, Johns MA, Berberich H, McCabe WR. Immunization with rough mutants of Salmonella minnesota: initial studies in human subjects. J Infect Dis 1988;158:301-11

35. Baumgartner JD, Wu MM, Glauser MP. Interpretation of data regarding the protection afforded by serum, IgG, or IgM antibodies after immunization with the rough mutant R595 of Salmonella minnesota. J Infect Dis 1989;160:347-9

36. Ziegler EJ, McCutchan JA, Fierer J, Glauser MP, Sadoff JC, Douglas $\mathrm{H}$, Braude AI. Treatment of gram-negative bacteremia and shock with human antiserum to a mutant Escherichia coli. N Engl J Med 1982;307:1225-30

37. Baumgartner J-D, Glauser MP, McCutchan JA, Ziegler EJ, van Melle G, Klauber MR, Vogt M, Muehlen E, Luethy R, Chiolero R, Geroulanos $S$. Prevention of gram-negative shock and death in surgical patients by prophylactic antibody to endotoxin core glycolipid. Lancet 1985;2:59-63

38. McCutchan JA, Wolf JL, Ziegler EJ, Braude AI. Ineffectiveness of singledose human antiserum to core glycolipid $(E$. coli $\mathbf{J} 5$ ) for prophylaxis of bacteremic, gram-negative infection in patients with prolonged neutropenia. Schweiz Med Wochenschr 1983;113(Suppl):40-5

39. Baumgartner J-D, Heumann D, Calandra T, Glauser MP. Antibodies to lipopolysaccharides after immunization of humans with the rough mutant Escherichia coli J5. J Infect Dis 1991;163:769-72

40. Calandra T, Glauser MP, Schellekens J, Verhoef J, the Swiss-Dutch JS Immunoglobulin Study Group. Treatment of gram-negative septic shock with human IgG antibody to Escherichia coli J5. J Infect Dis 1988;158:312-9

41. Zinner SH, McCabe WR. Effects of IgM and IgG antibody in patients with bacteremia due to gram-negative bacilli. J Infect Dis $\mathbf{1 9 7 6}$ 133:37-45

42. Appelmelk BJ, Verweij-van Vught AMJJ, Maaskant JJ, Schouten WF, Thijs LG, MacLaren DM. Monoclonal antibodies detecting novel structures in the core region of Salmonella minnesota lipopolysaccharide. Federation of European Microbiological Societies Microbiology Letters 1987;40:71-4

43. Pollack M, Raubitschek AA, Larrick JW. Human monoclonal antibodies that recognize conserved epitopes in the core-lipid A region lipopolysaccharides. J Clin Invest 1987;79:1421-30

44. Kirkland TN, Colwell DE, Michalek SM, McGhee JR, Ziegler EJ. Anal$y$ ysis of the fine specificity and cross-reactivity of monoclonal anti-lipid A antibodies. J Immunol 1986;137:3614-9

45. Dunn DL, Bogard WC Jr, Cerra FB. Efficacy of type-specific and crossreactive murine monoclonal antibodies directed against endotoxin during experimental sepsis. Surgery 1985;98:283-90

46. Miner KM, Manyak CL, Williams E, Jackson J, Jewell M, Gammon MT, Ehrenfreund C, Hayes E, Callahan LT III, Zweerink H, Sigal $\mathrm{NH}$. Characterization of murine monoclonal antibodies to Escherichia coli J5. Infect Immun 1986;52:56-62

47. Mutharia LM, Crockford G, Bogard C Jr, Hancock RE. Monoclonal antibodies specific for Escherichia coli J5 lipopolysaccharide: crossreaction with other gram-negative bacterial species. Infect Immun 1984;45:631-6

48. Nelles MJ, Niswander CA. Mouse monoclonal antibodies reactive with J5 lipopolysaccharide exhibit extensive serological cross-reactivity with a variety of gram-negative bacteria. Infect Immun 1984;46:677-81

49. Erich T, Schellekens J, Bouter A, Van Kranen J, Brouwer E, Verhoef $J$. Binding characteristics and cross-reactivity of three different antilipid A monoclonal antibodies. J Immunol 1989;143:4053-60

50. Aydintug MK, Inzana TJ, Letonja T, Davis WC, Corbeil LB. Cross- 
reactivity of monoclonal antibodies to Escherichia coli J5 with heterologous gram-negative bacteria and extracted lipopolysaccharides. J Infect Dis 1989;160:846-57

51. Appelmelk BJ, Verweij-van Vught AMJJ, Maaskant JJ, Schouten WF, DeJonge AJ, Thijs LG, Maclaren DM. Production and characterization of mouse monoclonal antibodies reacting with the lipopolysaccharide core region of gram-negative bacilli. J Med Microbiol 1988;26:107-14

52. Yang KD, Bathras JM, Shigeoka AO, James J, Pincus SH, Hill HR. Mechanisms of bacterial opsonisation by immune globulin intravenous: correlation of complement consumption with opsonic activity and protective efficacy. J Infect Dis 1989;159:701-7
53. Gorelick K, Scannon PJ, Hannigan J, Wedel N, Ackerman SK. Randomized placebo-controlled study of E5 monoclonal antiendotoxin antibody. In: Borrebaeck CAK, Larrick JW, eds. Therapeutic monoclonal antibodies. New York: Stockton Press, 1990:253-61

54. Ziegler EJ, Fisher CJ, Sprung CL, Straube RC, Sadoff JC, Foulke GE, Wortel CH, Fink MP, Dellinger RP, Teng NNH, Allen IE, Berger HJ, Knatterud GL, LoBuglio AF, Smith CR, the HA-1A Sepsis Study Group. Treatment of gram-negative bacteremia and septic shock with HA-1A human monoclonal antibody against endotoxin - a randomized, double-blind, placebo-controlled trial. N Engl J Med 1991;324:429-36 